\title{
IMPROVING THE STUDENTS' ABILITY IN TRANSLATING ENGLISH INTO INDONESIAN BASED ON DUFF'S PRINCIPLES
}

\author{
Radiah Hamid, Rati Pujiantri \\ English Education Department, Faculty of Teacher Training and Education \\ Muhammadiyah University of Makassar
}

\begin{abstract}
This research aimed at finding out the improvement of the students' ability in translating English into Indonesian specially for Recount text in terms of the meaning and style of the original text. The researcher used a Classroom Action Research (CAR) to explain the improvement, which was conducted in two cycles in which every cycle consisted of four meetings. The location of this research was taken at the second year of Junior High School 2 Sungguminasa with the number of the subject i.e. 36 students. The research findings indicate that the application of Duff's Principles is significant in improving the students' translating ability in terms of meaning and style of the original text. It is proved by the mean score of cycle I is 60.27 then improved to be 72.49 in cycle II. They are higher than the mean score of diagnostic test namely 56.45. It means that there is the improvement of the students' translating ability in terms of meaning and style of the original text.
\end{abstract}

Keyword: Ability, translating, English, Indonesian, Duff, principle

English is an International Language occupies the first position in the world communication today. This position makes English most widely used all over the world in all of aspects of human life. In our country, English plays an important role in international communication and in the development of education, economy, politics, tourism, and is one of resources in developing Indonesian Language. Further more, English is a major window for us to the out side world well spill peril for the future if we do not master it (Broughton, 1980:4).

In the era of the world development, all kinds of activities will encourage an increase in contact between people of various countries with different languages, communication occurs in overseas educations, multinational corporation, and diplomatic negotiations. All of these activities can inevitably create a great demand for translating skills. Due to the importance of translation activities, it can be confirmed that Indonesian students need to know how to translate English texts into their target language ( Bahasa Indonesia), the language they are learning and viceversa. The evidence shows that most Indonesian students find it difficult to translate English texts into Indonesian. Based on the research held by Fitriani (2004) on the students' ability in translating. The result of the research showed 
that the students have poor achievement. This might be caused by the students' low mastery of the English language. Consequently, they are unable to construct English sentence well or may be caused by the difficulties of translating process it self. In fact, translating one foreign language to another one is really difficult. It can be concluded that translating from one language to another especially from English into Indonesian is difficult. This is confirmed with Widyamartaya (1993:4) : " Translation is a sophisticated, advanced linguistic skill, not something for beginners.... It is valuable for communiaction if one alredy knows two language well.... Translation not only requires a good knowledge of two languages, but special training and experience.... To be able to talk two languages does not mean that one can translate between then effectively and skillfully. Switching from one to the other must be learn."

However, the result of English teaching in our country is still relatively low, because most of the techers usually spend their time in teching structure, reading and sentence patterns. They seldom think how to translate English texts of their students (Fitriani, 2004). Based on the statement mentioned above, the writer tries to see how far the application of English Instruction, especially the teaching of translation in connection in academic year 2012 / 2013 is chosen as the object of research. Then, she would like to know the result of the treatment, particularly the students' ability in translating English sentences into Indonesian.

\section{PROBLEM STATEMENT}

1. How is the improvement of the students' abilty in translating English into Indonesian based on Duff's Principles?

2. How does the implementation of Duff's Principles influence the students' ability in translating English into Indonesian?

\section{THE OBJECTIVE OF THE STUDY}

In relation to the problem statements, the objectives are:

1. To find out the improvement of the students' ability in translating English text into Indonesian based on the Duff's Principles. 
2. To find out the implementation of Duff's Principles can influence the students' ability in translating English into Indonesian.

\section{THE SIGNIFICANCE OF THE STUDY}

The findings of the research will offer significant information to the teachers of English in general, and for the teachers of English at the Junior High School 2 Sungguminasa in particular in response to the teaching translation.

\section{THE SCOPE OF THE STUDY}

In this research, the researcher will observe the students at the second year students of Junior High School 2 Sungguminasa in academic year 2012 / 2013 in translating English into Indonesian based on Duff's principles. This researcher will focus on meaning of the original text and the style of the original text in recount text. The resercher choose meaning and style of the original text because this aspect included in Duff's principles which the principles mentioned above can be a very useful guideline for translators to help them make some choices. The guidelines can be formulated in such away that basically the requirements of translations works have to be making sense, conveying the message of the original texts without omission and addition, having a natural and easy form of the expression, and producing a similar response to the readers.

\section{CONCEPT OF TRANSLATION}

Doing a translation is a complicated process. It needs a special way. If it is done in a simple way without considering some aspects, it too possible that the transaltion can not be understood by the reader. Nida and Taber (1982:12) say that translating consists in reproducing in the receptor language the closest natural equivalence of a source language message, firstly in terms of meaning and secondly in terms of style. According to them translators should use the closest natural equivalent either in the meaning or the style of the receptor language. In other words, the results of translation should not sound as translation but without changing the meaning of the source language. 
Larson (1984:3) says that translation consists of translating the meaning of the source language into the receptor language. This is done by going from the form of the first language to the form of a second language by way of semantic structure. It is meaning which is being transferred and must be held constant. Only the form changes. Catford (1965:20) states that translation may be defined as follows: the replacement of textual material in one language by equivalent textual material in another language. A similar definition of translation is mentioned by Newmark (1988:32) who says that translation is the super ordinate term for converting the meaning of any source language utterance to the target language.

\section{THE TYPES OF TRANSLATION}

According to Larson (1984:15) translation is classified into two main types, namely form-based and meaning-based translation. Form-based translation attemps to follow the form of the Source Language and is known as literal translation, while meaning-based translation makes every effort to communicate the meaning of the one language text in the natural forms of the receptor language. Such translation is called idiomatic translation.

Based on the purposes of translation, Brislin (1976:3-4) categorizes translation into four types, namely :

\section{a. Pragmatic Translation}

This type referring to the translation of message with an interst in accuracy of the information that was meant to be conveyed in the source of language form. Pragmatic translation is not concerned with other aspects of the original language version(e.g.aesthetic form) that would be considered as part of other three ends of translation.

\section{b. Aesthetic Poetic Translation}

In this type, the translator takes into account the effect emotion, and feelings, of the original language version, the aesthetic form (e.g. sonnet, heroic couplet, dramatic dialogue and novel) used by the original author, as well as many information in the message. The clearest examples are in the translation of literature. 


\section{c. Ethnographic Translation}

Its purpose is to expicate the cultural context of the source and the second language versions. With this as their goal translator have to be sensitive to the way words are used and must know how the words fit into the cultures that the use the source and the target languages

\section{d. Linguistic Translation}

This is concerned with equivalent meanings of the constituent morphemes of the source language and grammatical form, an example is language in a computer program and machine translation.

\section{THE PROCESS OF TRANSLATION}

Tou ( In Choliludin, 2005:31) presents the interpretation of the translation as follows :

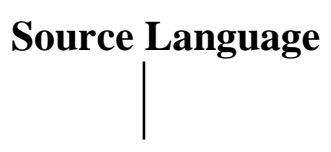

Analysis of meaning<smiles>[CH]C</smiles>

Discover the meaning

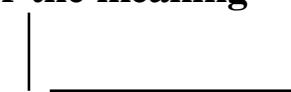

MEANING

In the diagram, there are four stages in the translation process that translators must follow in order to move from the source language into the target language namely analysis, discovery, transfer, and re-expression of meaning. The four translation stages are explained as follows :

a. Source language : the language that is to be translated.

b. Analysis : In the translation process, the first thing to do is understand the total meaning of the source text. There are three types of "meaning" that can be determined in the analysis of meaning of the source text (Nida and Taber, 
1984:34), namely : grammatical meaning, referential meaning and connotative meaning.

c. Discovery : understanding the source meaning involves much more than what the words refer to. Language should be related to contexts in order to really understand the text.

d. Meaning : The translation should reflect accurately the meaning of the original text. Nothing should be arbitrarily added or removed, though occasionally part of the meaning can be transposed.

e. Transfer: In this stage, the translator should be able to transfer through him as a variable of discovered textual meaning from the source to the target language.

f. Re-express : In this stage, the translator tries to look for the correct equivalent of words, expression and sentence in the target language.

g. Target language : a language into which a text has to be translated or a language other than one's native language that is being learned.

\section{THE CRITERIA OF A GOOD TRANSLATION}

Talking about a good translation is constitue all vision translators. But, whether the vision can be gotten by translators easily. Whereas the criteria of a good translation are :

1. The translation should give a complete transcript of idea of the original work.

2. The style and manner of writing should be the same character with the original.

3. The translation should be have all the eases of the original composition. ( Tytler : 1790 )

\section{THE DUFF'S PRINCIPLES IN TRANSLATION}

According to Duff (1989) there are some general principles which are relevant to all translation : 
1. Meaning. The translation should reflect accurately the meaning of the original text. Nothing should be arbitrarily added or removed, though occasionally part of the meaning can be transposed.

2. Form. The ordering of words and ideas in translation should match theoriginal as closely as possible. But differences in language often require changes in the form and order of words. When in doubt, underline the original text the words on which the main stress falls.

3. Register. Languages differ greatly in their levels of formality in a given context. To resolve these differences, the translator must distinguish between formal or fixed expressions and personal expressions.

4. Source language influence. It should sound natural, natural patterns should be suggested.

5. Style and clarity. The translator sholud not change the style of the original. But if the text is sloppily written, or full of tedious repetitions, the translator may, for the reader's sake, correct the defects.

6. Idiom. Idiomatic expressions should be adapted. Idiomatic expressions including similies, metaphors, proverbs, and sayings, jargon, slang, and colloquialisms and phrasal verbs are often untranslatable.

The principles mentioned above can be a very useful guideline for translators to help them make some choices.

\section{THE APPLICATION OF THE DUFF'S METHOD}

The application of the Duff's Method is consists of four steps, they are : sentences identification, sentence analysis, the analysis of meaning, and translate idiomatically ( Choliludin: 2005 ). He would like to give explanation about them as follows:

\section{Sentence identification}

It consists of two points :

a. What the sentence is talking about. 
The identificated part is the first knowledge about what the sentence is talking about, such as about education, healthy, history, language, archaeology, art, religion, politic, economic, entertainment, culture, etc.

b. The type of the sentence.

The identificated part also including the situation of the sentence in the text. Is it simple sentence or complex sentence which including complex subject, complex verb, or complex object.

\section{Sentence analysis}

During the analysis stage, the translators task in the process of the translation is to analyze the surface structure of the source language text in term or grammatical relationship and meaning or words or combination of words. The analysis is focused on grammatical relationship ( subject, verb, object, and complement ) and meaning of words or groups of words.

3. Understand the total meaning of the source language (the analysis of meaning ).

There are three types of "meaning" that can determined in the analysis of meaning of the source text ( Nida and Taber in Choliludin, 2005 ), namely :

a) Grammatical meaning

When one thinks of meaning, it is almost inevitably in terms of words or idioms. Generally grammar is taken for granted since it seems to be merely a set of arbitrary rules about arrangements, rules that must be followed if one wants to understand, but not rules themselves that seem to have any meaning. A comparison of 'John hit Bill' and 'Bill hit John' should convince us that grammar has meaning. It is the first word which performs the action of the second word, and the word identifies the goal of the action specified by the second word. 'Did you go' and 'You did go' can be altered with the same patterns of intonations, but the grammatical differnce of order provides quite a different meaning.

b) Referential meaning

This refers to words as symbols which refer to objects, event, abstracts, and relations. For example : 
- He bought a hammer. (Dia membeli sebuah palu)

- They will hammer the nail. (Mereka akan memukul paku dengan palu)

The distinct meaning of the terms "hammer" is very closely marked by the occurrence of these terms in quite a different contrast with verbs.

c) Connotative meaning

Connotative meaning refers to how the users of the language react, whether positively or negatively, to the words and their combination. Sometimes, the associations surrounding some words become so strong that people avoid using them at all.

\section{Translate text idiomatically (Idiomatic Translation).}

Idiomatic translation use the natural forms of the receptor language both in the grammatical constructions and in the choices of lexical items. Larson (1984) says that idiomatic translation use the natural forms of the receptor language both in the grammatical constructions and in the choices of lexical items. A truly idiomatic translation does not sound like a translation. It sounds like it was written originally in the receptor language. Therefore, a good translation will try to translate idiomatically. This is his or her goal. In practice, however, it is hard to consistently translate idiomatically or literally. These translation are often a mixture of literal and idiomatic forms of language. Translation then falls on a continuum from very literal to literal, to modified literal, to near idiomatic, to idiomatic, and may fall, even more on the unduly free (Larson: 1984).

a. If they add extraneous information not in the source text.

b. If they change the meaning of source language.

c. f they distort the facts of the historical and cultural setting of the source language text.

\section{RESEARCH METHOD}

This research used a Classroom Action Research (C.A.R). This classroom action research is conducted in two cycles, and it will be continued in the cycle 3 if the result of cycle 2 is not significant. It aims at observing the employing or 
implementation of Duff's Principles in improving the students' ability in translating English into Indonesian.

\section{Cycle I}

1. The Planning

Before start to teach the teacher must prepared the materials for teaching the students. The plan as follow:

a. Made lesson planning based on the curriculum, and arrange material of lesson planning and it should based on the teaching of translating.

b. Made diagnostic test / pretest .

c. Made the observation sheet for observe the condition of learning process.

d. Arranged the result of pretest to know the improvement of the students in translating English into Indonesian based on Duff's Principles.

2. Action

This activity had scenario learnign process, it should based on the genre based approach in learning English specially in translating English into Indonesian based on Duff's Principles as like that :

a. The teacher Introduced Duff's Principles to the students.

b. The teacher gave a short explanation to the students about Duff's Principles.

c. The teacher gave the students a source text, and asked them to translate the text carefully.

d. The students tried to analyzed of each sentences.

e. After translate carefully, the students wrote each of the difficult words.

f. After that, students is asked one by one about the difficult words in the text.

g. The students is asked to read the result of their translation.

3. Observation

In the observation phase the researcher will observe by using observation sheet. This observation as follow:

a. Situation of teaching and learning activity

b. The students' attendance 
c. The students' respond of the material

d. The students' achievement

4. Reflection

After collecting data, the researcher evaluated the teaching learning process. Then, the researcher reflects herself by seeing the finding of the observation, whether the teaching learning process in translating English into Indonesian based on Duff's Principles is good to employ in teaching and learning process or not.

Cycle II

It was like cycle in the cycle I, cycle II also consisted of planning, action, observation and reflection as follows:

1. Planning

The way that have been done :

a. Continued the activities that have been done in the first cycle.

b. Improved the weakness in the first cycle.

c. Made planning again in the scenario learning process from the result of cycle I reflection.

d. Action research improved.

2. Action

In this stage, action is done to improve the result based on the cycle reflection I. The stages done are the same with the previous cycle that is to say, to do improvement of the applied teaching method.

3. Observation

In the reality the observation done at the cycle II is almost same as the done observation at cycle I.

4. Reflection

Based on the achieved result of the observation is collected and analyzed. From the result of the writer, the writer can draw conclusion that the students' ability in transalating English into Indonesian based on Duff's Principles can improved. 


\section{RESEARCH VARIABLES AND INDICATORS}

This research has two variables : The Implimentation of Duff's Principles as the independent variable and the students' achievement in translating as the dependent variable. The indicators of variables are : Meaning and Style of the original text.

\section{RESEARCH SUBJECT \& INSTRUMENT}

The research subject of this classroom action reseach was the second year student of Junior High School 2 Sungguminasa. In this research, the researcher used test translating and observation to got data about their ability in the learning translating especially in English into Indonesian based on Duff's Principles. Collecting data in this classroom action research as follow:

\section{Test}

The test consist of three tests are diagnostic test was administered before teaching implementation of the first cycle. The cycle I test was administered after the implementation of the first cycle to measure the improvement the students' ability in translating English into Indonesian based on Duff's Principles. The cycle II test was administered at the end of the teaching implementation of the second cycle. These three tests used to measure the improvement the students' ability in translating English into Indonesian of the two cycles.

\section{Observation}

It will be used to find out the students' participation, motivation, and activeness during the teaching and learning process. The observation sheet consists of four items. It will be write in one paper. It contains are:
a) The students' attendance
b) The students' learning process
c) The students' respond of the material
d)The students' active in doing the task

\section{DATA COLLECTION}

To collect the data is done with the following procedures: 
1. Data source: The data source in this research is the students' achievement in translating English into Indonesian before getting the translating material based on Duff's Principles.

2. The researcher gave test to the students. It is done after implementing of Duff's Principles in translating English into Indonesian in the class or in the observation of classroom action research, which will be done in every cycle. The following activities are:

a. The researcher explained about the procedure of test.

b. The researcher asked the students to prepared source text.

c. The researcher asked the students to translate their source text.

d. The students collected their translating result

Classifying the score of the students

\begin{tabular}{|c|c|c|}
\hline Categories & Score & Indicator \\
\hline Excellent & $\begin{array}{l}86-90 \\
(\mathrm{~A})\end{array}$ & $\begin{array}{l}\text { Delivery is natural; almost not like } \\
\text { Translation; not error spelling;not error } \\
\text { Grammar, not error using term. } \\
\text { The ordering of ideas in the translation } \\
\text { match with the original as closely as } \\
\text { possible. } \\
\text { Translator reflect accurately the } \\
\text { meaning of the original text. }\end{array}$ \\
\hline Very good & $\begin{array}{l}76-85 \\
\text { (B) }\end{array}$ & $\begin{array}{l}\text { Not meaning distors; not awkward } \\
\text { literal translation; not error using term; } \\
\text { there are two-three error } \\
\text { grammar/spelling. } \\
\text { Nothing change in the style of the } \\
\text { original. }\end{array}$ \\
\hline Good & $\begin{array}{l}61-75 \\
(\mathrm{C})\end{array}$ & $\begin{array}{l}\text { Not meaning distors; there are literal } \\
\text { translation that awkward, but relative no } \\
\text { more from } 15 \% \text { from all text, with the } \\
\text { result that not like translation; error } \\
\text { grammar and idiom relative no more } \\
\text { from } 15 \% \text { from all text. There are one - } \\
\text { two using terms not standard/common. } \\
\text { There are one-two error spelling. }\end{array}$ \\
\hline Poor & $\begin{array}{l}46-60 \\
\text { (D) }\end{array}$ & $\begin{array}{l}\text { Like as translation; there are meaning } \\
\text { Distors; there are literal translation that } \\
\text { awkward, but no more than } 25 \% \text {. There } \\
\text { Are some error idiom and/grammar, but }\end{array}$ \\
\hline
\end{tabular}




\begin{tabular}{|l|l|l|}
\hline & & $\begin{array}{l}\text { relative no more than 25\% fro all text. } \\
\text { There are one-two using terms not } \\
\text { standard /not common and/ not real very } \\
\text { like as translation; many more literal } \\
\text { translation that awkward } \\
\text { (relative more than 25\% from all text); }\end{array}$ \\
\hline Very poor & $\begin{array}{l}\text { Meaning distors and error using term } \\
\text { more than 25\% all text. }\end{array}$ \\
\hline
\end{tabular}

(Dipenum, 1999)

Evaluative checklist:

\begin{tabular}{|l|c|}
\hline \multicolumn{1}{|c|}{ Criteria } & Score \\
\hline 1. Meaning of original text & $\mathbf{5 0 - 1 0 0}$ \\
\hline $\begin{array}{l}\text { a. Translator reflect accurately the meaning of the original } \\
\text { text. }\end{array}$ & \\
\hline $\begin{array}{l}\text { b. Not meaning distors; not awkward literal translation; not } \\
\text { error using term; there are two-three error grammar/spelling. }\end{array}$ & \\
\cline { 2 - 2 } 2. Style of the Original Text & $\mathbf{5 0 - 1 0 0}$ \\
\hline a. Nothing change in the style of the original. & \\
\hline b. Nothing deviation in the style of the original & \\
\hline
\end{tabular}

( Mertler, 2001)

\section{DATA ANALYSIS}

The data is get from cycle I and cycle II were analyzed through the following steps:

1. To find out the mean score of the students' test, the researcher uses the following formula:

$$
\bar{X}=\frac{\sum X}{N}
$$

Where:

$\bar{X} \quad=$ Mean score

$\sum X=$ Total score

$N=$ Number of student

(Gay 1981:298)

2. After collected the data of the students, the researcher classified the score of the students. To classify the students' score, there were seven classifications which were used as follows:

3. a. 86 to 90 is classified as excellent 

b. 76 to 85 is classified as very good
c. 61 to 75 is classified as good
d. 46 to 60 is classified as poor
e. 20 to 45 is classified as very poor

(Dipenum, 1999)

4. To Calculate the percentage of the students' score, the formula which was used as follows:

$\mathrm{P}=\frac{F}{N} \boldsymbol{x} 100$

Where:

$$
\begin{aligned}
& \mathrm{P}=\text { Percentage } \\
& \mathrm{F}=\text { Number of correct } \\
& \mathrm{N}=\text { Number of sample }
\end{aligned}
$$

(Sudjana in Awalia 2009: 32)

\section{FINDING AND DISCUSSION}

This chapter presents the findings and the discussion of the research. The finding consist of the data obtained through the achievement test aimed to know the student's achievement before and after being taugh the materials of translation based on Duff's Principles, and the discussion deals with the description and interpretation of the findings.

1. The students's Achievement in Translating Recount Text.

The application of Duff's Principles in improving the students'ability in translating focused with Meaning and Style of the original text in recount text. The improvement of the students' abilty in translating english into indonesian especially recount text at the second year of Junior High School 2 Sungguminasa can be seen clearly in the following table :

Table.1 : The Improvement of the Students' Ability in Translating

\begin{tabular}{|l|l|l|l|l|l|l|}
\hline \multirow{2}{*}{ Indicators } & \multicolumn{4}{|l|}{ The students' score } & \multicolumn{3}{l|}{ Improvement } \\
\cline { 2 - 7 } & D-Test & Cycle I & Cycle II & DT $\rightarrow$ CI & CI $\rightarrow$ CII & DI $\rightarrow$ CII \\
\hline Meaning & 56,25 & 60,13 & 72,91 & 3,88 & 12,78 & 16,66 \\
\hline Style & 57,91 & 60,55 & 72,08 & 2,64 & 11,53 & 14,17 \\
\hline$\sum X$ & 114,16 & 120,68 & 144,99 & 6,52 & 24,31 & 30,83 \\
\hline
\end{tabular}




\begin{tabular}{|l|l|l|l|l|l|l|}
\hline $\bar{X}$ & 57,08 & 60,34 & 72,5 & 3,26 & 12,16 & 15,42 \\
\hline
\end{tabular}

The table above indicates that the improvement of the students' translating ability after given action in cycle I - cycle II is quite significant $(12,16)$. It also shows that the result of Diagnostic-Test is the lowest mean score. The students' achievement in Diagnostic-test is categorized as poor in the lowest score $(57,08)$. After evaluation in cycle I and cycle II, there is a significant improvement of the students' translating ability where the result of cycle I is categorized as good in maximum score $(60,34)$ and cycle II categorized as very good which almost reach very good category $(72,5)$. Therefore, the students' translating ability improved significantly from Diagnostic Test until cycle II $(15,42)$.

In the table above also indicates that the indicators of students' translating ability improve significantly in which Diagnostic-Test, the students' translating in terms of meaning of the original text is 56,25. After evaluation in cycle $I$, the students' achievement of translating in terms of meaning of the original text becomes 60,13 and in cycle II becomes 72.91. The students' achievement of translating in terms of style of the original also improves from Diagnostic-test to cycle I namely 57,91 to 60,55 and in cycle II is 72,08 . To see clearly the improvement of the students' writing ability, the following chart is presented:

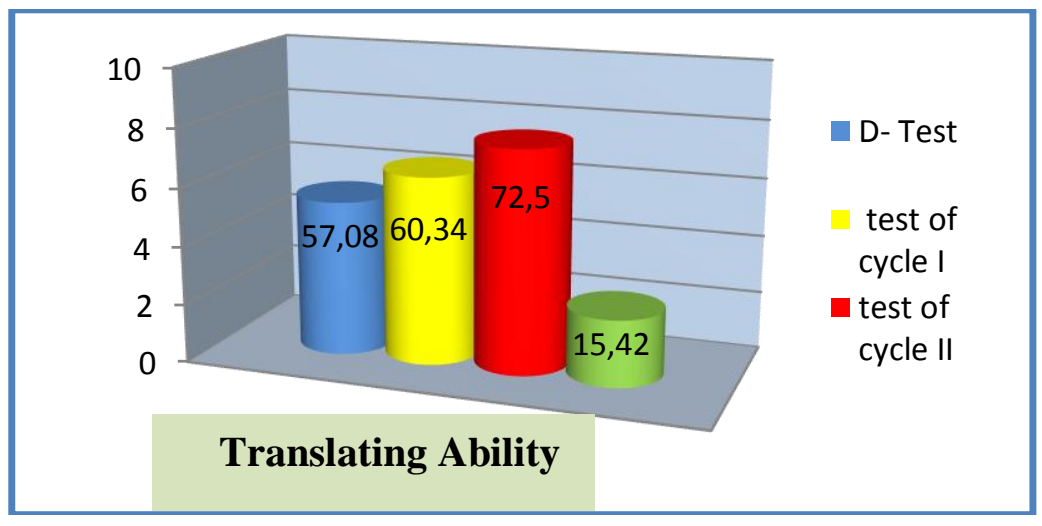

Figure 1: The Improvement of the Students' Translating Ability

The chart above shows the improvement of the students' translating which in cycle II is higher $(72,5)$ than cycle I $(60,34)$ and Diagnostic -Test $(57,08)$. (Cycle II $\geq$ Cycle I $\geq$ Diagnostic - Test). It also shows that the result of Diagnostic-Test is the lowest mean score achievement. The students' achievement 
in D- test is categorized as poor. After evaluation in cycle I and cycle II, there is significant improvement of the students' translating where the result of cycle I is categorized as fair and cycle II categorized as good. The improvement is shown clearly in the chart above, that is 15,42 .

To see clearly the improvement of the students' translating ability in terms of meaning of the original text, the following chart is presented:

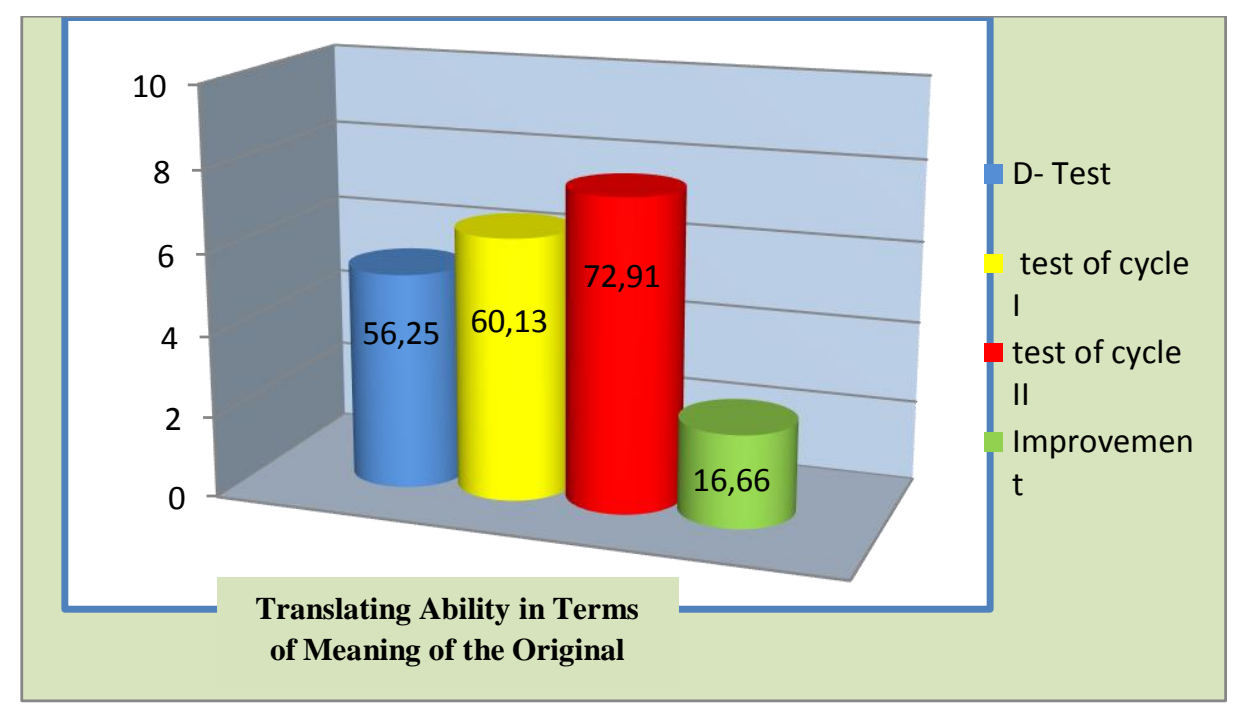

Figure 2: The Improvement of the Students' Translating Ability in Terms of Meaning of the Original

The graphic above shows the students' improvement in translating ability in this case the meaning of original text based on Duff's Principles at the second year of Junior High School 2 Sungguminasa. The graphic present the students' score in the cycle I and Cycle II with focused on the meaning of the original text, from the graphic it's known that there is an improvement of the means score of noun in the cycle I from 60,13 to 72,91 . To see clearly the improvement of the students' translating ability in terms of Style of the original text, the following chart is presented: 


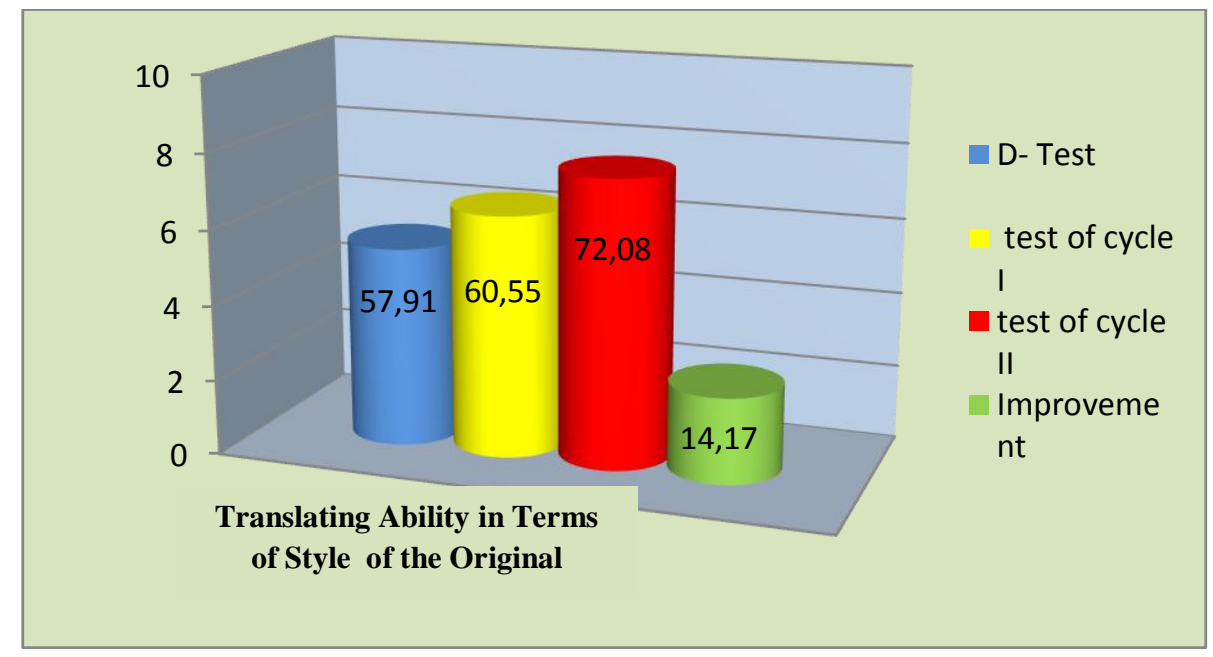

\section{Figure 3: The Improvement of the Students' Translating Ability in Terms of Style of the Original}

The graphic above shows the students' improvement in translating ability in this case the style of original text based on Duff's Principles at the second year of junior high school 2 sungguminasa. The graphic present the students' score in the cycle I and Cycle II with focused on the style of the original text, from the graphic it's known that there is an improvement of the means score of noun in the cycle I from 60,55 to 72,08 .

\section{Observation Result}

The result of observation of the students' activeness in teaching and learning process toward the application of Duff's Principles in improving the students' translating ability at the second year of junior high school 2 sungguminasa in class VIII.6 which is conducted in 2 cycles during 8 meetings is taken by the observer through observation sheet. It can be seen clearly through the following table:

\begin{tabular}{|c|c|c|c|c|c|}
\hline \multirow{3}{*}{ Cycle } & \multicolumn{4}{|c|}{ Students' Participation } & \multirow{2}{*}{ Improvement } \\
\cline { 2 - 5 } & \multicolumn{4}{|c|}{ Meeting } & 4th \\
\hline & $1 \mathrm{st}$ & $2^{\text {nd }}$ & 3rd & \\
\hline \multirow{2}{*}{ Cycle 1 } & $58,59 \%$ & $72,79 \%$ & $73,75 \%$ & $72,22 \%$ & $68,33 \%$ \\
\hline
\end{tabular}




\begin{tabular}{|l|l|l|l|l|l|} 
& & & & \\
Cycle 2 & $73,6 \%$ & $74,3 \%$ & $76,38 \%$ & $77,77 \%$ & $75,51 \%$ \\
\hline
\end{tabular}

Table 2: The Percentage of Students' Participation

Based on the table above, the researcher can explain that the students' observation in learning translating in cycle I was good with percentage of first meeting until fourth meeting $58.59,72.79,73.75,72.22$, with the mean score $68.33 \%$. Percentage of the first meeting until fourth meeting of cycle II are 73.60, $74.30,76.38,77.77$, with the mean score $75.51 \%$. It means that the students' activeness in learning process was increased. The data was also shown in the cart below:

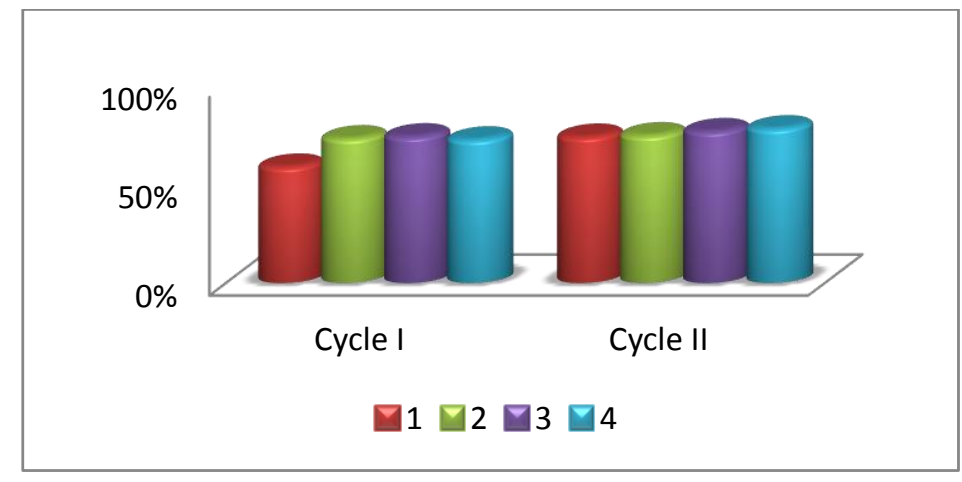

Figure 4 : The Percentage of Students' Participation in Learning process Based on the figure above, shows the students' observation in translating process based on Duff's Principles at the second year of junior high school 2 Sungguminasa. This figure presented the students' situation during teaching learning process in translating from cycle I to cycle II from the feature it's known that there was the changing of students' situation learning from cycle I to cycle II.

\section{DISCUSSION}

In this part, the research described the teaching and learning process in the classroom. The students learning how to translate recount text in terms of meaning and style of original text. In this case, to improve students' ability in translating, the research based on Duff's Principles. The research finding indicated that the students' ability in translating based on Duff's principles showed the improvement of the students' achievement in translating recount text in terms of meaning and style of the original text . From this improvement showed 
the process from the cycle I to cycle II. The process covered about their ability to make the result of translating that was based on Duff's principles in terms of meaning and style of original.

The researcher has change the activity more interesting in cycle II so that students could show the improvement, in the first cycle the research gave enough explanation about Duff's principles in translating but the students seemed like confused. But in cycle II the students really enjoyed the method because the researcher gave explanation intensively and motivation when teaching and learning process. At the first the researcher found that the students difficult to translate a text into Indonesian. So the principles did some interesting efforts from cycles I to cycle II to improved the students' ability in translating. The researcher prepared well before did the second cycle. The researchers know what the weakness and the strengths, because the researcher did reflection.

There was some process that research could explain as follow:

a. At the first meeting, the researcher did the observation by be an observer in the class while the English class teacher was teaching. Then the researcher gave a diagnostic test by asked the students to translate a recount text into Indonesian. It was aimed to know the base ability of the students in translating.

b. At the first meeting in cycle 1, researcher checked students name and explained what they were going to do, then explain what is Duff's principles. Besides that, the researcher told the students that it was the individual work. After that researcher told about the material that they were going to learn.

c. At the second meeting in cycle 1, researcher checked their name. After that researcher continued the explanation about the materials. Then the researcher gave a recount text to the students to translate into Indonesian while the researcher gave motivation and spirit to the students to improve their ability in translating. The researcher asked the students to follow the method that has explained to them in the first meeting. Besides that, the researcher gave the clear explanation about something that the students asked to him.

d. At the third meeting in cycle 1, researcher checked their name and then gave some advices to the students. At that meeting, the researcher only did some 
feedback to the students (seemed like giving some questions and answer), it was caused by there were many students took a permit that day. The feedback that the teacher did was about the obstacles of the students in using the method. So, the students more understand about the material.

e. At the fourth meeting in cycle 1, researcher checked their name. After that researcher wrote a recount text in the whiteboard and then asked the students to translate into Indonesian based on Duff's principles.

The result after applying action of translating based on Duff's principles shows the students' score improve. This score was taken from the ability of the students' to fulfill the indicators' criteria that is meaning and style of the orginal text. Total and mean score was calculated by using the formula in data analysis. After that, the research used the score of test to find out the students improvement percentage. The students' translating ability in cycle I was taking an improvement.

a. At the five meeting in cycle 2, researcher checked their name. After that researcher told that the result of the cycle 1 did not reach the criteria minimum score so the cycle would be continue to the cycle 2 . Then, researcher told the students the weakness that should be repaired in the next cycle and gave any chances to the students to ask about their obstacles during learning process.

b. At the six meeting in cycle 2, researcher checked their name. After that researcher gave more detail explanation about the method and the material. Also, researcher gave more spirit to the students to improve their translating ability.

c. At the seven meeting in cycle 2, researcher checked their name. After that researcher continued the explanation about the materials, also in that meeting researcher gave special attention to the students that the understandings about the material were low. The seventh meeting the research shared his experience that was aimed to increase the students' motivation in learning.

d. At the eight meeting in cycle 11, researcher checked their name. After that researcher wrote, a recount text in whiteboard again then asked the students to 
translate into Indonesian with a hope that the students can reached the criteria minimum score.

The result of cycle II in translating based on Duff's principles showed that the students took the significant improvement. This score was taken from the ability of the students' to fulfill the indicators' criteria that is meaning and style of original text. After that, the research used the score of cycle I and cycle II to find out the students' improvement percentage. The result showed that the translating ability of the students was improved.

It means that the students' achievement in translating especially in translating recount text into Indonesian based on Duff's principles in the classroom was good and increased. By using these principles, students and the researcher were cooperating each order in improving students' knowledge. The whole result based on the finding above shown that after calculating the students' ability in filled the criteria of , there were significant improvement of the students' ability in translating based on Duff's principles. It is proved the students' means score in cycle II higher than students' mean score in cycle I test.

\section{BIBLIOGRAPHY}

Brislin, W.R. 1976. Translation Application and Research. New York : Gardenes Press, Inc.

Broughton, G. 1980. Teaching English as a Foreign Language. Second Edition. London : Routledge and Paul.

Catford, J.C. 1965. A Linguistic Theory of Translation. London: Oxford University.

Choliludin. 2005. The Technique of Making Idiomatic Translation. Jakarta: Kesaint Blanc.

Direktorat Pendidikan Menengah Umum. 1999. Penelitian Pembelajaran Bahasa Inggris. Jakarta: Depdikbud.

Duff, A. 1989. Translation. London : Oxford University Press

Gay, L.R. 1981. Education Research : Competencies for Analysis and Application. Florida : Belland Howed. 
Larson, M. 1984. Meaning Based Translation USA University Press of America. Inc. Learner's Packet Dictionary. London: Oxford University Press.

Longman. 2002. Language Activator. New Edition. Pearson Education Limited Printed in China.

Mertler, C.A. 2001. Designing Scoring Rubrics For Your Classroom. Pratical Assessment, Research and Evaluation. Retrieved September 15, 2012 from http://pareonline.net/getvn.asp?v=7\&n=25.

Mettetal, G. 1997. Improving Teaching Trough Classroom Action Research. Indiana University South Bend.

Newmark, P. 1988. Approaches to Translation. New York: Pergamon Press.

Nida, E.A and Taber, Charles R. 1982. The Theory and Practice of Translation. Leiden, E.J Brill

Saranto, D.S. 2008. An Annotated Translation of The Mutiny of The Bounty. Journal of a thesis by Universitas Gunadarma.

Sudjana. 1999. Metode Stastika. Bandung: PT Gramedia.

Suling, L. 2007. An Annoted Translation of The President's Mistress. Journal of a thesis by Universitas Gunadarma.

Tytler, A.F. 1790. Essay on The Principles of Translation.

Widyamartaya. 1993. Seni Menerjemahkan. Cet.III. Yogyakarta : Kanishing. 